\title{
The dependency of intermediate size problem responses upon sets in human Ss
}

\author{
KATIIERINE E. BA KER 1 and JAMES ULNESS, 2 Department \\ of Psychology, University of Nebraska, Lincoln. Nebr.
}

As predicted, human Ss trained with three sizes of squares, intermediate size being "correct," responded relationally to transposition tests regardless of similarity between training and test stimuli, providing sets (indexed by a task during training) were "relational"; but if sets were "absolute," absolute responding was shown on similar tests, relational on dissimilar. Thus, had data from Ss with different sets been grouped, the resultant similarity function would represent no actual $S$. This new analysis appears fruitful in understanding findings not consistent with previous theoretical formulations.

Gestalt theory, S-R theory, and adaptation level theory analyses of transposition in the intermediate size problem encounter difficulties in accounting for demonstrated increased responding on a relational basis as test stimuli become less similar to training stimuli. (For theoretical analyses, see Goldstein, Krantz, \& Rains, 1965; Spence, 1942; Zeiler, 1963a, 1963b, 1964.) Each of these theories assumes (a) Ss are alike with respect to the stimulus property used as a cue, and (b) no $S$ has more than one basis for responding; but these assumptions appear doubtful for human Ss. If S's conceptualization of the problem included more than one responding basis, then the generally used responses with mutually exclusive classifications of absolute or relational would not provide adequately definitive measures.

During training, $S$ appears to acquire an approach to the problem which determines his performance on transposition. A problem approach may be viewed as a set, in Harlow's (1949) learning set sense, revealed in a "set index" from modes of responding in a problem task. Also a problem approach involves so-called cognitive sets including $S$ 's recognition of salient features of the problem, these sets being assessable by "set report" information on S's knowledge of bases of responding which he may or may not choose to employ in performance. Thus $S$ adopts a mode of responding (set index) and this need not correspond to nor exhaust his recognized possible responding principles (set report).

The present view is that, during training on the intermediate size problem, each $\mathrm{S}$ forms sets in both senses of the term, different Ss having different possible ones. In accordance with expanded learning set theory, in approaching subsequent problems, $S$ acts on whatever sets he previously formed, providing the sets apply to the new problem. A transposition test with dissimilar stimuli presents no difficulty to Ss set to respond on a relational basis, but an absolute responding set is not applicable. An $S$ with an absolute responding set who recognizes the relational basis, too, can change his mode of responding to relational for dissimilar tests; but, without such recognition, he might fail to respond, respond randomly, or change to relational responding if he discovers the applicability of the relational principle in retrospect when faced with the test.

Hypothesis 1 states that Ss will differ in sets; some indexing as absolute, others as relational in adopted response mode, and within indexed groups, some reporting knowledge of only a single responding principle, others both. Hypothesis 2 is that transposition responses depend upon which sets $S$ formed in training and how similar transposition stimuli are to training stimuli: Ss who index as adopting a relational mode of responding give relational transposition responses regardless of stimulus similarity, but Ss who index as adopting an absolute mode employ this mode for similar tests and abandon it for dissimilar tests, likely in favor of the relational mode. Hypothesis 3 asserts that Ss are capable of identifying the original stimuli on the basis of absolute size, regardless of chosen response modes.

Subjects. Two groups totaling 156 Introductory Psychology students, with males slightly in the majority, served in two group sessions. Each $\mathrm{S}$ supplied four types of data.

Materials. Individual dittoed booklets were constructed to contain the following pages: (1) instructions; (2) 17 pages of 12 training trials with one set indexing trial after each two training trials but the last two; (3) one transposition test trial; (4) a set reporting form.

Stimuli for training, set indexing, and transposition testing were selected three-iiem subsets of a graded series of seven outline squares ranging from 4 to $30.12 \mathrm{~cm}^{2}$ with each successively larger square increasing in area by a factor of 1.4. On each training trial, stimuli Nos. 2, 3, and 4 (with No. $1=4 \mathrm{~cm}^{2}$ ) appeared in line, $1 / 2 \mathrm{in}$. apart, on a $51 / 2 \times 8$ in. page, with positions of each stimulus counterhalanced over trials to preclude a positional responding basis. "(") was typed over Stimulus 3, regardless of position, signifying this to be "correct" (by virtue of absolute size). Five set indexings were done by $S$ writing $C$ over the "correct" one of the subset 1 , 2 , and 3, 2 being scored "relational," and 3 "absolute" as to responding mode. Transposition test pages contained either Stimuli 3, 4, 5 (Hi), or Stimuli 4, 5, 6 (Med), or Stimuli 5. 6,7 (Lo similarity) in one of various positional patterns, and no $\mathrm{C}$.

Set reporting forms asked $\mathrm{S}$ on what basis he had been making "correct" choices, and what, if any, other basis could have been used. Thus $S$ indicates if he recognizes the absolute or relational principle only, or both.

An S's ability to identify the squares used in training was shown on a separate $81 / 2 \times 11$ in. page containing all seven squares, in order for some $\mathrm{Ss}$, unordered for others.

Procedure. Booklets (each with one of three types of transposition tests) were randomly distributed to $S s$ in a group, printed instructions read aloud, and progress through the booklet begun with $E$ signaling when to turn pages. Instructions were to study carefully each set of figures on a page for $20 \mathrm{sec}$, noting the $\mathrm{C}$ over the "correct" figure on some pages and supplying the $C$ on pages where there was none. Working ahead or referring to previous pages was not allowed. Three minutes were given for the set reporting form and bookle ts were collected. Training stimuli identification sheets were distributed and $1 \mathrm{~min}$ was allowed before collection.

\section{RESULTS}

Sets. Set reporting form answers classified each $\mathrm{S}$ as recognizing an absolute responding principle (Absol), a relational principle (Rel), or both principles (Both). Table 1, showing numbers of Ss so classified on cognitive sets in each transposition test group, indicates about equal frequencies of Rel reports and Both reports ( $42.3 \%$ and $44.9 \%$, respectively), but many fewer Absol reports $(12.8 \%)$. This distribution of set report types is not strictly maintained in all test groups $\left(x^{2}=8.39 . p<10>5\right.$ with $4 \mathrm{df}$ ), suggesting some Med and Lo similarity Ss may have had only the Absol set before testing, but report Rel or Both after discovering absolute responding inapplicable, reviewing training. and discerning the other principle.

Set indexing, scored Absol or Rel. measured each S's responding mode set during training. A strict criterion of consistent responding on the last four trials was employed for classification. Overall, $84 \%$ were classifiable, the $16 \%$ with inconsistent performance primarily coming from those later reporting Both, who might be expected to vary responding principles over trials. Single principle reporters provided indexes in $90-95 \%$ of the cases.

Table 2 presents frequencies of types of set reports within set index groups. If $S$ reports only a single principle after transposition testing, the set index obtained prior to testing agrees $(96.1 \%)$, but if both are reported $(\mathrm{N}=52), 42.3 \%$ index Rel, 57.7\% index Absol. Of 81 Rel index Ss, 27.2\% report Both, while $60.0 \%$ of $50 \mathrm{Absol}$ index Ss report Both. These distributions suggest some Absol index Ss only discern and report the relational principle. too, after transposition tests.

Hypothesis 1 is clearly supported with regard to set indices, and with some exceptions, there is reason to believe that set

Table I

Frequency of Ss Giving Types of Set Reports in Each Transposition Test Group

\begin{tabular}{lcccc}
\hline \multirow{2}{*}{$\begin{array}{c}\text { Type } \\
\text { Report }\end{array}$} & \multicolumn{3}{c}{ Stimulus Similarity of Test } & \\
\cline { 2 - 4 } & Hi & Med & Lo & Total \\
\hline Absol & 10 & 3 & 7 & 20 \\
Rel & 17 & 30 & 19 & 66 \\
Both & 25 & 21 & 24 & 70 \\
Total & 52 & 54 & 50 & 156 \\
\hline
\end{tabular}


Table 2

Frequency of Ss Giving Each Type of Set Report Within Set Index and Transposition Test Groups

\begin{tabular}{|c|c|c|c|c|c|}
\hline \multirow{2}{*}{$\begin{array}{c}\text { Set } \\
\text { Index }\end{array}$} & \multirow{2}{*}{$\begin{array}{l}\text { Type } \\
\text { Report }\end{array}$} & \multicolumn{3}{|c|}{ Stimulus Similarity of Test } & \multirow[b]{2}{*}{ Total } \\
\hline & & $\mathrm{Hi}$ & Med & Lo & \\
\hline Rel & $\begin{array}{l}\text { Rel } \\
\text { Buth } \\
\text { Absol }\end{array}$ & $\begin{array}{r}16 \\
13 \\
0\end{array}$ & $\begin{array}{r}26 \\
4 \\
0\end{array}$ & $\begin{array}{r}17 \\
5 \\
0\end{array}$ & $\begin{array}{r}59 \\
22 \\
0\end{array}$ \\
\hline Absol & $\begin{array}{l}\text { Rel } \\
\text { Both } \\
\text { Absol }\end{array}$ & $\begin{array}{l}0 \\
9 \\
8\end{array}$ & $\begin{array}{r}1 \\
10 \\
2\end{array}$ & $\begin{array}{r}2 \\
11 \\
7\end{array}$ & $\begin{array}{r}3 \\
30 \\
17\end{array}$ \\
\hline Total & & 46 & 43 & 42 & $131^{*}$ \\
\hline
\end{tabular}

*22 Ss giving reports were unclassifiable as to index due to inconsistent use of absolute or relational responses on the last four indexing trials, and three indexed Ss gave no reports.

Table 3

Frequency of Types of Transposition Test Responses by Different Set Index Groups

\begin{tabular}{lrcr}
\hline \multirow{2}{*}{$\begin{array}{l}\text { Type } \\
\text { Response }\end{array}$} & Rel & Set Index & \\
\cline { 2 - 3 } & 74 & Absol & Total \\
Rel & 7 & 22 & 96 \\
Absol & 0 & 28 & 35 \\
Fail & 81 & 3 & 3 \\
Total & 53 & 134 \\
\hline
\end{tabular}

Table 4

Frequency of Types of Transposition Test Responses by Different Set Report Groups

\begin{tabular}{|c|c|c|c|c|}
\hline \multirow{2}{*}{$\begin{array}{l}\text { Type } \\
\text { Response }\end{array}$} & \multicolumn{3}{|c|}{ Set Report } & \multirow[b]{2}{*}{ Total } \\
\hline & Rel & Absol & Both & \\
\hline $\begin{array}{l}\text { Rel } \\
\text { Absol } \\
\text { Total }\end{array}$ & $\begin{array}{c}57(2)^{*} \\
5(1) \\
62\end{array}$ & $\begin{array}{c}3(3) \\
14(14) \\
17\end{array}$ & $\begin{array}{c}36(17) \\
16(13) \\
52\end{array}$ & $\begin{array}{r}96 \\
35 \\
131 \\
\end{array}$ \\
\hline
\end{tabular}

*Number of Absol index Ss falling in the cell.

Table 5

Percentage of Each Set Index Group Giving Different Types of Transposition Test Responses

\begin{tabular}{|c|c|c|c|c|c|}
\hline \multirow{2}{*}{$\begin{array}{c}\text { Type } \\
\text { Response }\end{array}$} & \multirow{2}{*}{$\begin{array}{c}\text { Set } \\
\text { Index }\end{array}$} & \multicolumn{3}{|c|}{ Stimulus Similarity of Test } & \multirow[b]{2}{*}{ Total } \\
\hline & & $\mathrm{Hi}$ & Med & Lo & \\
\hline Rel & $\begin{array}{l}\text { Rel } \\
\text { Absul }\end{array}$ & $\begin{array}{c}93.4(29)^{*} \\
0.0(17)\end{array}$ & $\begin{array}{l}86.7(30) \\
26.7(15)\end{array}$ & $\begin{array}{l}95.5(22) \\
76.2(21)\end{array}$ & $\begin{array}{l}91.4(81) \\
41.5(53)\end{array}$ \\
\hline Absol & $\begin{array}{l}\text { Rel } \\
\text { Absol }\end{array}$ & $\begin{array}{r}6.6(29) \\
100.0(17)\end{array}$ & $\begin{array}{l}13.3(30) \\
60.0(15)\end{array}$ & $\begin{array}{r}4.5(22) \\
18.3(21)\end{array}$ & $\begin{array}{r}8.6(81) \\
52.8(53)\end{array}$ \\
\hline Fail & $\begin{array}{l}\text { Rel } \\
\text { Absol }\end{array}$ & $\begin{array}{l}0.0(29) \\
0.0(17)\end{array}$ & $\begin{array}{r}0.0(30) \\
13.3(15)\end{array}$ & $\begin{array}{l}0.0(22) \\
4.5(21)\end{array}$ & $\begin{array}{l}0.0(81) \\
5.7(53) \\
\end{array}$ \\
\hline
\end{tabular}

*Number of Ss upon which percentage in cell is based.

Table 6

Percentage Giving Relational Transposition Test Responses in Each Set Report Group Within the Two Set Index Groups

\begin{tabular}{|c|c|c|c|c|c|}
\hline \multirow{2}{*}{$\begin{array}{c}\text { Set } \\
\text { lndex }\end{array}$} & \multirow{2}{*}{$\begin{array}{r}7 y p \\
\text { Ryent } \\
\end{array}$} & \multicolumn{3}{|c|}{ Stimulus Similarity of Test } & \multirow[b]{2}{*}{ Total } \\
\hline & & $\mathrm{Hi}$ & Med & Lo & \\
\hline Rel & $\begin{array}{l}\mathrm{Rel} \\
\mathrm{B} \cdot \mathrm{HL}_{\mathrm{H}}\end{array}$ & $\begin{array}{r}100.0 \\
88.8\end{array}$ & $\begin{array}{l}(50.0)^{*} \\
95.8\end{array}$ & $\begin{array}{l}(83.3) \\
100.0\end{array}$ & $\begin{array}{l}82.8 \\
94.8\end{array}$ \\
\hline Absol & $\begin{array}{l}\text { Alsiol } \\
\text { Both }\end{array}$ & $\begin{array}{l}0.0 \\
0.0\end{array}$ & $\begin{array}{r}60.0 \\
(0.0)\end{array}$ & $\begin{array}{r}100.0 \\
42.9\end{array}$ & $\begin{array}{l}57.7 \\
41.2\end{array}$ \\
\hline
\end{tabular}

*Based on six or ferier $S_{S}$ so of questimable reliability.

reports given aller transposition testing confirm the predicted cognitive set diffelences among Ss.

Transposition. lable 3 presents types of transposition responses over all lypes of tests broken down according to S's set index. Scoring was Rel if the intermediate size square of the subset received the $C$. Absol if the one closest to absolute size was chosen. Ckirly. Rel responding is predominant over all tests, Absol less uscid, and failures were recorded for three Absol index Ss. Note that more of the Ss index Rel than Absol, and proportionately more $S s$ indexing Rel give Rel test responses than do Absol index Ss. A $\chi^{2}$ test on the upper $2 \times 2$ portion of Table 3 yields a value of $34.99, p<.01$ with $1 \mathrm{df}$.

Table 4 shows how test responses are distributed over set report groups. Table 4 indicates that Absol reporters from the Absol index group contribute very few of the Rel test responses, while Both reporters from the Absol index group frequently give Rel responses. Table 4 gives a $\chi^{2}$ of $38.34, p<.01$ with $2 \mathrm{df}$.

Effects of similarity between test and training stimuli are revealed when data are separated by type of test $S$ received. Table 5 shows the per cent of each set index group that gave particular test responses. The Rel index Ss generally give Rel responses on tests regardless of similarity, but Absol index Ss respond Absol to similar tests and Rel to dissimilar ones, or fail. Table 6 presents Rel test responses only (remaining per cents being Absol responses) to show that Rel index Ss behave much alike in all transposition tests, whether they report Rel or Both, and Absol index Ss with Absol or Both reports show comparable changes in test responses over test similarity.

Results show relational responding increases with decreased similarity over all Ss taken together $(58.7,74.4,88.1 \%$ for $\mathrm{Hi}$, Med, and Lo similarity, respectively). However, this change is largely due to Ss with Absol sets who abandon the absolute mode of responding when given dissimilar tests and add their number to those responding relationally in transposition when stimuli are less similar. These data confirm Hypothesis 2 in all its aspects.

Identification of training stimuli. With ordered stimuli, $94.3 \%$ of 87 Ss identified the $C$ square, and $84.5 \%$ of 71 Ss did so with unordered stimuli. Half the Ss with correct $\mathrm{C}$ square identifications also identified the other two training stimuli. Hypothesis 3 is considered satisfactorily supported, although identification appears reduced by having stimuli out of order.

\section{DISCUSSION}

This study essentially replicates the troublesome finding of increasing tendencies to respond relationally in transposition tests with decreasing similarity between test and training stimuli, but it does so as a predicted result rather than a deviant outcome. Different Ss form different sets in training, and performance on transposition is a function of similarity of test stimuli for Ss with certain sets and not for others, although virtually all Ss "know" the "correct" square by absolute size. Therefore, it appears that the new analysis has merit: theories assuming all Ss follow an identical law seem defeated at the start, and the notion of adoption of some dominant learning set by each $\mathrm{S}$ with its later application in transposition, if possible, is likely a fruitful alternative to previously offered theories of intermediate size problem responding, especially with human Ss.

Assessing sets created problems of contamination of test responses by set indexing and/or of set reporting by tests. Suggestive evidence of a slight effect of the latter was presented; and the favoring of relational or two-principle set reports and relational test responding may be, in part, due to the former. Naturally other dimensions and extents of the test similarity parameter need exploration and results of alternative set measurement procedures are required for detailing the general relationships demonstrated.

\section{REFERENCES}

GOLDSTEIN, H., KRANTZ, D. L., \& RAINS, J. C. (Eds.), Controversial issues in learning. New York: Appleton-Century-Crofts, 1965.

HARLOW, H. The formation of learning sets. Psychological Review, $1949,56,51-65$.

SPENCE. K. W. The basis of solution by chimpanzees of the intermediate size problem. Journal of Experimental Psychology, 1942, 31, 247-271.

ZEILER, M. D. New dimensions of the intermediate size problem: neither absolute nor relational response. Journal of Experimental Psychology, 1963a, 66, 588-593.

ZEILER, M. D. The ratio theory of intermediate size discrimination. Psychological Review, 1963b, 70, 516-533.

ZEILER, M. D. Transposition in adults with simultaneous and successive stimulus presentation. Journal of Experimental Psychology, 1964, 68. 103-107.

\section{NOTES}

1. Now at State University College at Buffalo.

2. Now at Cuncordia College, Moorhead, Minn. 